\title{
Kinetics of nutrient removal in an on-site domestic wastewater treatment facility
}

\author{
Va Vandith $^{1}$, Ahmad Soleh Setiyawan ${ }^{1}$, Prayatni Soewondo ${ }^{1}$, Pom Bophann $^{1}$ and Hardjono ${ }^{1}$ \\ ${ }^{1}$ Department of Environmental Engineering, Faculty of Civil and Environmental Engineering, Institut Teknologi Bandung, JL \\ Ganesha 10 Bandung 40132, Indonesia
}

\begin{abstract}
Domestic wastewater from office building has not been maintained well especially in the areas where the sewerage system is unavailable. The aims of this research were to investigate the performance and kinetics of nutrient removal in an on-site domestic wastewater treatment facility which consists of anaerobic and aerobic systems for treating wastewater from office building. The experimental data obtained from the variations of COD:N:P ratio 250:28:2.5, 350:38:2.9, 450:47:3.3, and 600:60:3.7 with three different HRT $48 \mathrm{~h}, 24 \mathrm{~h}$, and $12 \mathrm{~h}$. A One-way ANOVA was performed to investigate the effects of HRT and initial concentration of TN and TP on the performance of nutrient removal. In order to obtain the kinetic coefficients, First Order, Second Order and Stover-Kincannon Models were employed. The results showed that maximum TN and TP removal efficiency were $56 \%$ and $86 \%$, respectively. The results of one-way ANOVA showed that HRT and initial concentration of TN and TP gave the significant effects on nutrient removal $(p<0.05)$. Second Order and Stover-Kincannon Models were found to be more appropriate models for prediction of TN removal in this facility. Controlling HRT and C: N: P ratio may keep good performance of nutrient removal in this facility.
\end{abstract}

\section{Introduction}

Presently, environmental destruction is becoming on a global scale, and people are showing a dramatic rise in concern for environmental protection. Water pollution is one of the major causes of the environmental pollution and destruction. As can be seen clearly, most of the developing countries including Indonesia are having a problem of water pollution due to an insufficient amount of wastewater treatment plant or sewerage system to treat wastewater. As a result, untreated domestic wastewater containing nitrogen and phosphorus is discharging into the environment without purifying action which will accelerate the water pollution such as eutrophication potential.

Subsequently, an on-site wastewater treatment facility is one of the preferable alternative technologies to treat nitrogen and phosphorus from domestic wastewater in low-density communities. The treatment facility is also introduced by USEPA in 1997 for decentralizing domestic wastewater treatment facilities where the sewerage system is unavailable. In Japan, Johkasou has been known as an advanced domestic wastewater treatment tank which has been widely used as a decentralized wastewater treatment system and it still continues to expand into other countries $[1,2]$.

Johkasou is an advanced wastewater treatment facility which contains anaerobic filter tanks, contact aeration tank, sedimentation tank, and disinfection tank [3]. It has been implemented as alternative treatment system in the rural areas of Japan, in addition from other areas that do not have wastewater treatment plants $[4,5]$. The treatments in anaerobic filter tank are to separate solid matter, store sludge, and degrade organic matter by anaerobic microorganisms. Moreover, contact aeration tank is employed to degrade organic matter, oxidizes ammonia by aerobic microorganisms, and to return sludge with recirculation water to the anaerobic tank. Sedimentation tank can separate suspended solid from treated water through sedimentation, return sludge to contact aeration tank and send supernatant to disinfection tank. The last treatment unit is disinfection tank which supernatant is disinfected by chlorine tablets to get free from pathogenic microorganism. The effluent from Johkasou facilities can be discharged directly into the water body since the nitrogen and phosphorus concentration are in the permissible discharge criteria [6].

On-site domestic wastewater facility which consists of anaerobic and aerobic systems has been developed and become famous in developed countries and it also could be implemented in developing countries. However, it is hard to use this facility directly for individual house in Indonesia because of high cost and controlling. One of the strategies is to use this facility for communal use such as office building in Indonesia, but there is no information about the kinetics of nutrient removal of this facility for treating domestic wastewater from office building. Therefore, this research was to know the kinetics and performance of nutrient removal in an onsite domestic wastewater treatment facility which consists of anaerobic and aerobic systems for treating domestic wastewater from office building.

\section{Method}

The experiment was conducted in water quality laboratory of environmental engineering department of

\footnotetext{
${ }^{*}$ Corresponding author: vandith va@yahoo.com
} 
Institut Teknologi Bandung for a period of six months from August 2015 to February 2016.

\subsection{Experimental Set up}

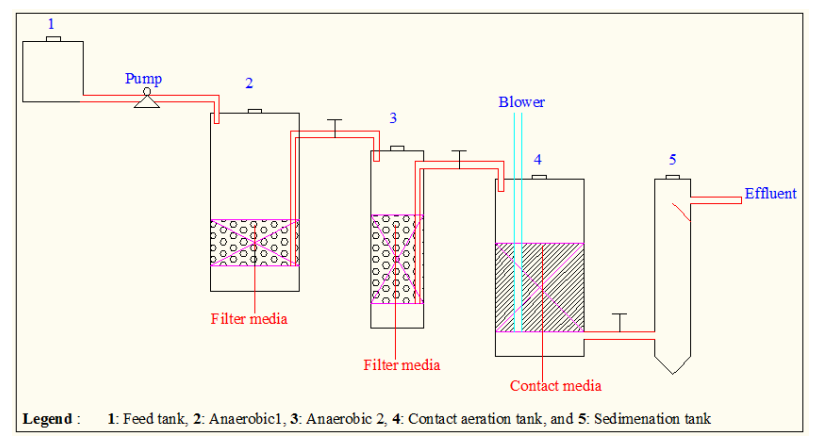

Fig. 1. Lab-scale model of on-site domestic wastewater treatment facility.

A lab-scale model of an on-site domestic wastewater treatment facility used in this research is shown in Fig.1.This facility consists of four compartments which are anaerobic 1, anaerobic 2, contact aeration tank, and sedimentation tank. In order to feed the wastewater to this facility, the feed tank was set in front of the facility and there was the water pump to pump it to anaerobic1 continuously with flow meter used to control the flow rate. The air flow rate was controlled by the air pump and placed diffuser at the bottom tank and at the middle of the contact aeration tank to supply the oxygen inside this compartment. The working volume of reactor is 100 L. In anaerobic 1, the volume of reactor is $32 \mathrm{~L}$ and bioball ball type was filled in order to let microbes attach it. The anaerobic 2, the volume is $19 \mathrm{~L}$ and bio-ball ball type were used as filter media in order to let microbes grow. Furthermore, the contact aeration tank, the volume is $34.5 \mathrm{~L}$ and bio-ball rambutan type was employed as contact media in this compartment. The final compartment is sedimentation tank, the volume is $14.5 \mathrm{~L}$ where the remaining suspended materials will settle before discharging to the environment.

\subsection{Wastewater Preparation}

Wastewater used in the experiment was the synthetic wastewater which had been characterized based on the characteristics of domestic wastewater from office building. The variations of CNP ratio were determined based on the characteristic of domestic wastewater from office building. The synthetic wastewater was used to control the variation of inlet concentration required in order to determine the kinetics of nutrient removal in this facility. The compositions of synthetic wastewater used were glucose $\left(\mathrm{C}_{6} \mathrm{H}_{12} \mathrm{O}_{6}\right)$, ammonium chloride $\left(\mathrm{NH}_{4} \mathrm{Cl}\right)$, potassium nitrate $\left(\mathrm{KNO}_{3}\right)$ and sodium nitrite $\left(\mathrm{NaNO}_{2}\right)$, and potassium dihydrogen phosphate $\left(\mathrm{KH}_{2} \mathrm{PO}_{4}\right)$ used as source for COD: N: P ratio, respectively [7].

\subsection{Experimental Design and Reactor operation}

The reactor was initially inoculated with domestic wastewater from dormitory and was carried out with a batch condition which was used for seeding process. The wastewater was filled into the reactor with the volume of $90 \%$ of total volume of the reactor. In the seeding process, glucose was used as a main source of the substrate because it was considered as a degradable source by microorganisms, and ammonium chloride $\left(\mathrm{NH}_{4} \mathrm{Cl}\right)$ with potassium phosphate $\left(\mathrm{KH}_{2} \mathrm{PO}_{4}\right)$ were used as nitrogen and phosphorus sources, respectively. The reactor started up involving daily feeding of synthetic wastewater until the microbes started to form on the media after three weeks, especially in the contact aeration tank in batch condition. The measurements of COD were made everyday to see how biomass grow against the elimination of organic matter. $\mathrm{pH}, \mathrm{DO}$, and Temperature were measured everyday to know the environmental conditions of biological wastewater treatment in this facility.

After the seeding process, the reactor was allowed to do the acclimatization process. The synthetic wastewater was pumped continuously to this facility. The wastewater used was synthetic wastewater for providing a continuous source of completely biodegradable organic matter and maintain the constant feed concentration into the reactor. The acclimatization process was finished when it reached the steady state condition at the variation of C: N: P ratio 250:2.8:2.5 and HRT 48h.

Based on Table 1, in the running process, this facility was supplied synthetic wastewater with the concentration varied from the lowest to the highest which flexible to characteristic of wastewater from office building fluctuation in real condition at the field with three different hydraulic retention times $48 \mathrm{~h} 24 \mathrm{~h}$ and $12 \mathrm{~h}$. The hydraulic retention time and C: N: P ratio were changed to another variation after it reached the steady-state condition.

In this experiment, sampling points were taken in five points namely: inlet, the effluent of anaerobic 1 , the effluent of anaerobic 2, the effluent of contact aeration tank and effluent of sedimentation tank. TN and TP were taken and analyzed daily before and after it reached the steady state condition. $\mathrm{pH}, \mathrm{DO}$ and Temperature were measured every compartment everyday to observe the environmental condition of biological wastewater treatment before and after it reached the steady-state condition. TSS and VSS were analyzed only when the running process was finished in order to know the average biomass inside the anaerobic tanks, contact aeration tank, and overall reactor. In order to know the biomass in the anaerobic tanks, aerobic tank, and overall reactor, the number of media is known in these compartments. The number of media is 512,550 , and 750 in anaerobic 1 , anaerobic 2 , and contact aeration tank, respectively. Three media of each tank were taken and measured to know the

Table 1. Variation of C: N: P ratio and HRT values in lab-scale model of on-site domestic wastewater treatment facility.

\begin{tabular}{|l|l|l|l|l|l|l|}
\hline No & $\begin{array}{c}\text { COD } \\
(\mathbf{m g} / \mathbf{L})\end{array}$ & $\begin{array}{c}\text { TN } \\
(\mathbf{m g} / \mathbf{L})\end{array}$ & $\begin{array}{c}\text { TP } \\
(\mathbf{m g} / \mathbf{L})\end{array}$ & $\begin{array}{c}\mathbf{Q} \\
(\mathbf{L} / \mathbf{h})\end{array}$ & $\begin{array}{c}\mathbf{V} \\
(\mathbf{L})\end{array}$ & $\begin{array}{c}\text { HRT } \\
(\mathbf{h})\end{array}$ \\
\hline \multirow{4}{*}{ I } & 250 & 28 & 2.5 & 2.08 & 100 & 48 \\
\cline { 2 - 7 } & 350 & 38 & 2.9 & 2.08 & 100 & 48 \\
\cline { 2 - 7 } & 450 & 47 & 3.3 & 2.08 & 100 & 48 \\
\cline { 2 - 7 } & 600 & 60 & 3.7 & 2.08 & 100 & 48 \\
\hline \multirow{4}{*}{ II } & 250 & 28 & 2.5 & 4.17 & 100 & 24 \\
\cline { 2 - 7 } & 350 & 38 & 2.9 & 4.17 & 100 & 24 \\
\cline { 2 - 7 } & 450 & 47 & 3.3 & 4.17 & 100 & 24 \\
\hline
\end{tabular}




\begin{tabular}{|l|l|l|l|l|l|l|}
\hline & 600 & 60 & 3.7 & 4.17 & 100 & 24 \\
\hline \multirow{4}{*}{ III } & 250 & 28 & 2.5 & 8.33 & 100 & 12 \\
\cline { 2 - 7 } & 350 & 38 & 2.9 & 8.33 & 100 & 12 \\
\cline { 2 - 7 } & 450 & 47 & 3.3 & 8.33 & 100 & 12 \\
\cline { 2 - 7 } & 600 & 60 & 3.7 & 8.33 & 100 & 12 \\
\hline
\end{tabular}

attached biomass. The average biomass is summed of attached biomass and suspended growth biomass.

\subsection{Analytical Techniques}

The following parameters were analyzed according to the standard method for the examination of water and wastewater: COD (SMEWW 5220-B), TSS (SMEWW 2540-D), VSS (SMEWW 2540-I), TN (SMEWW 4500B), TP (SMEWW 4500-P-D), Temperature (SMEWW 2550), $\mathrm{pH}\left(\mathrm{SMEWW} 4500 \mathrm{H}^{+}\right.$), and DO (SMEWW 4500-0-G). A one-way analysis of variance (ANOVA) was used to test the significant effect of HRT, initial TN and TP concentration on nutrient removal at the significant 0.05 level by using Microsoft Office Excel 2013.

\subsection{Determination of Kinetics}

There are three common kinetic models used to predict substrate removal as follows [8]:

\subsubsection{First Order Substrate Removal Model}

The rate of change in substrate concentration in the system with assuming the first order model for substrate removal could be expressed as follows [9].

$$
-\frac{d S}{d t}=\frac{Q S_{o}}{V}-\frac{Q S}{V}-k_{1} S
$$

Under the pseudo-steady state conditions, the rate of change in substrate concentration due to accumulation $(-\mathrm{dS} / \mathrm{dt})$ is negligible and the equation given above can be modified as:

$$
\frac{S_{o}-S}{H R T}=k_{1} S
$$

The value of the first-order kinetic constant can be obtained by plotting (So-S)/HRT versus $\mathrm{S}$ in (2). The value of $\mathrm{k}_{1}$ is obtained from the slope of the straight line.

\subsubsection{Second Order Substrate Removal Model}

The general equation of a second-order model is given below [10].

$$
-\frac{d S}{d t}=k_{2(s)} \cdot\left(\frac{S}{S_{o}}\right)^{2}
$$

If (3) is integrated and then linearized, (4) results:

$$
\frac{S_{o} \cdot H R T}{S_{o}-S}=H R T+\frac{S_{o}}{k_{2(s)} X}
$$

If the second term of the right part of this equation is accepted as a constant, the equation will be modified as below:

$$
\frac{S_{o} \cdot H R T}{S_{o}-S}=a+b H R T
$$

The value of a (per day) and $b$ (without unit) will be drawn as $y$-intercept and the slope of the line, respectively. In the above-mentioned equation, HRT is per day, and pollutant removal speed constant or $\mathrm{k}_{2(\mathrm{~s})}$ is calculated by a $=\mathrm{S}_{0} /\left(\mathrm{k}_{2(\mathrm{~s})} \times \mathrm{X}\right)$. $\mathrm{X}$ is average biomass inside the reactor. If (So-S)/So expresses the substrate removal efficiency and is symbolized as $E$. Therefore, (6) can be written as follows:

$$
\frac{H R T}{E}=a+b H R T
$$

\subsubsection{Stover Kincannon Model}

In this model, the substrate utilization rate is expressed as a function of the organic loading rate by monomolecular kinetic for biofilm reactors such as rotating biological contactors and biological filters. The equation of the Stover-Kincannon model is as follows [11].

$$
\begin{array}{r}
\frac{d S}{d t}=\frac{Q}{V}\left(S_{o}-S\right) \\
\frac{d S}{d t}=\frac{U_{\max }\left(Q S_{o} / V\right)}{K_{B}+\left(Q S_{o} / V\right)}
\end{array}
$$

If $(-\mathrm{dS} / \mathrm{dt})$ is taken as $\mathrm{V} /\left[\mathrm{Q}\left(\mathrm{S}_{0}-\mathrm{S}\right)\right]$, which is the inverse of the removed substrate loading rate and this is plotted against the inverse of the total loading rate $\mathrm{V} / \mathrm{QS}_{\mathrm{o}}$, a straight line portion of intercept $1 / \mathrm{U}_{\max }$ and a slope of $\mathrm{K}_{\mathrm{B}} / \mathrm{U}_{\max }$ resulted.

$$
\frac{V}{Q\left(S_{o}-S\right)}=\frac{K_{B}}{U_{\max }} \cdot \frac{V}{Q S_{o}}+\frac{1}{U_{\max }}
$$

The substrate balance for the reactor at steady-state can be written as follows:

$$
Q S_{o}=Q S+V \frac{d S}{d t}
$$

Substituting of equation (8) and (10) gives

$$
Q S_{o}=Q S+\frac{U_{\max }\left(Q S_{o} / V\right)}{K_{B}+\left(Q S_{o} / V\right)} * V
$$

This expression can be solved for either the effluent substrate concentration (12) or the removal efficiency of the reactor (13) by substituting kinetic constants $U_{\max }$ and $\mathrm{K}_{\mathrm{B}}$.

$$
\begin{aligned}
& S=S_{o}-\frac{U_{\max } S_{o}}{K_{B}+\left(Q S_{o} / V\right)} \\
& E=\frac{S_{O}-S}{S_{O}}=\frac{U_{\max }}{K_{B}+\left(Q S_{o} / V\right)}
\end{aligned}
$$

\section{Result and Discussion}

\subsection{Effect of HRT on TN and TP removal}

After initial acclimatization of biofilm growth on support media, TN removal was obtained at hydraulic retention time $48 \mathrm{~h}$ when it reached the steady state condition. The synthetic wastewater which had been characterized based the domestic wastewater from office building was fed along with $\mathrm{C}$ : $\mathrm{N}$ : $\mathrm{P}$ ratio. The reactor was continuously operated at three different hydraulic 
retention times $48 \mathrm{~h}, 24 \mathrm{~h}, 12 \mathrm{~h}$ and four different initial TN concentrations $27 \mathrm{mg} / \mathrm{L}, 38 \mathrm{mg} / \mathrm{L}, 47 \mathrm{mg} / \mathrm{L}$ and 60 $\mathrm{mg} / \mathrm{L}$, respectively. According to Fig. 2, the maximum TN removal efficiency can be achieved at $\mathrm{C}: \mathrm{N}$ : P ratio $350: 38: 2.9$ at $24 \mathrm{~h}$ of HRT was $56 \%$ which was the optimum condition. In order to identify the effect of HRT on the performance of TN removal in facility, one-way ANOVA was performed to three principle components of HRT values.

\begin{tabular}{|c|c|c|c|}
\hline 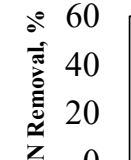 & & $\stackrel{\mathrm{C}}{\mathrm{C}}$ & \\
\hline & HRT $48 \mathrm{~h}$ & HRT 24h & HRT $12 \mathrm{~h}$ \\
\hline$\square 27 \mathrm{mg} / \mathrm{L}$ & 52 & 48 & 38 \\
\hline च $38 \mathrm{mg} / \mathrm{L}$ & 55 & 56 & 41 \\
\hline 口 $47 \mathrm{mg} / \mathrm{L}$ & 45 & 49 & 38 \\
\hline$\nabla 59 \mathrm{mg} / \mathrm{L}$ & 48 & 55 & 44 \\
\hline
\end{tabular}

Fig. 2. Variation of TN removal at different HRT values in lab-scale model of an on-site domestic wastewater treatment facility.

\begin{tabular}{|c|c|c|c|}
\hline \multicolumn{4}{|l|}{ d0 } \\
\hline 80 & & $\mathbb{W}$ & \\
\hline 40 & 即 & $=$ & $\mathbb{W} \equiv$ \\
\hline$\hat{F}$ & HRT $48 \mathrm{~h}$ & HRT $24 \mathrm{~h}$ & HRT $12 \mathrm{~h}$ \\
\hline$\square 2.5 \mathrm{mg} / \mathrm{L}$ & 25 & 57 & 52 \\
\hline - $2.9 \mathrm{mg} / \mathrm{L}$ & 38 & 77 & 48 \\
\hline (a $3.3 \mathrm{mg} / \mathrm{L}$ & 63 & 80 & 51 \\
\hline$\Xi 3.7 \mathrm{mg} / \mathrm{L}$ & 64 & 86 & 54 \\
\hline
\end{tabular}

Fig. 3.

Variation of TP removal at different HRT values in lab-scale model of an on-site domestic wastewater treatment facility.

The result of one-way ANOVA showed the effect of HRT on TN removal in the overall reactor at the 0.05 level.

TP removal was obtained at hydraulic retention time $48 \mathrm{~h}$ when it reached the steady state condition. The synthetic wastewater which had been characterized based on domestic wastewater from office building was fed along with $\mathrm{C}$ : $\mathrm{N}$ : $\mathrm{P}$ ratio. The facility was continuously operated at three different hydraulic retention times $48 \mathrm{~h}, 24 \mathrm{~h}, 12 \mathrm{~h}$ and four different initial TP concentrations $2.5 \mathrm{mg} / \mathrm{L}, 2.9 \mathrm{mg} / \mathrm{L}, 3.3 \mathrm{mg} / \mathrm{L}$, and $3.7 \mathrm{mg} / \mathrm{L}$, respectively. Fig. 3 showed that maximum TP removal efficiency can be achieved at $\mathrm{C}: \mathrm{N}$ : $\mathrm{P}$ ratio 600:59:3.7 at $24 \mathrm{~h}$ of HRT was $86 \%$ which was the optimum condition. In order to identify the effect of HRT on the performance of TP removal in facility, oneway ANOVA was performed to three principle components of HRT values. The result of one-way ANOVA gave the significant effect of HRT on TP removal in the overall reactor of lab-scale model of an on-site domestic wastewater treatment facility at the 0.05 level.

\subsection{Effect of initial TN and TP concentration on TN and TP removal}

Based on Fig. 4, it showed the variation of TN removal at different initial TN concentrations in the facility. This facility was fed with four different initial concentrations, $28 \mathrm{mg} / \mathrm{L}, 38 \mathrm{mg} / \mathrm{L}, 47 \mathrm{mg} / \mathrm{L}$ and $60 \mathrm{mg} / \mathrm{L}$ and operated with three different hydraulic retention times $48 \mathrm{~h}, 24 \mathrm{~h}$, and $12 \mathrm{~h}$. The One-way ANOVA was performed to four principle components of initial $\mathrm{TN}$ concentration. The effect of initial TN concentration was evaluated and all of the variations gave the significant effect on TN removal in lab-scale model of an on-site domestic wastewater treatment facility with the maximum TN removal can be

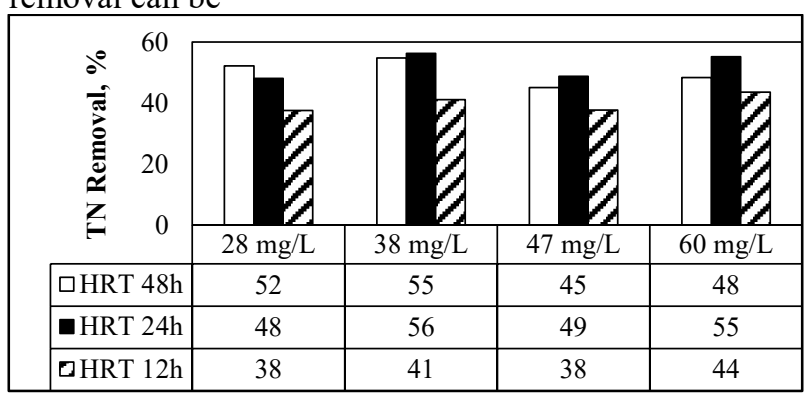

Fig. 4.

Variation of TN removal at different initial TN concentration in lab-scale model of an on-site domestic wastewater treatment facility.

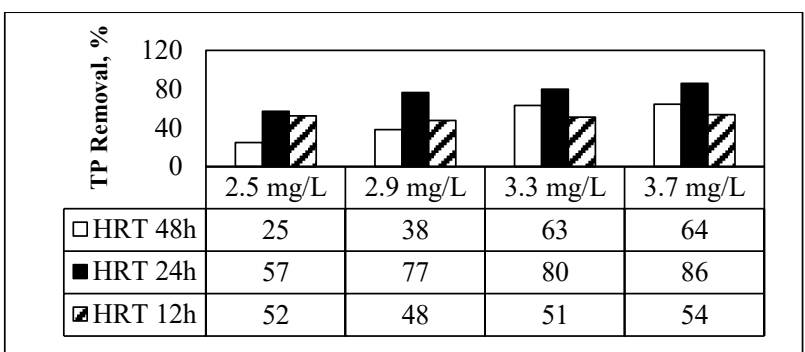

Fig. 5.

Variation of TP removal at different initial TP concentration in lab-scale model of an on-site domestic wastewater treatment facility.

achieved at HRT 24h and C:N:P ratio 350:38:2.9 was $56 \%$.

According to Fig. 5, it showed the variation of TP removal at different initial TP concentrations in the facility. This facility was fed with four different initial concentrations, $2.5 \mathrm{mg} / \mathrm{L}, 2.9 \mathrm{mg} / \mathrm{L}, 3.3 \mathrm{mg} / \mathrm{L}$ and 3.7 $\mathrm{mg} / \mathrm{L}$ and operated with three different hydraulic retention times $48 \mathrm{~h}, 24 \mathrm{~h}$, and $12 \mathrm{~h}$. A One-way ANOVA was performed to four principle components of initial TP concentration. The result of one-way ANOVA showed that all of the variations gave the significant effects of initial TP concentration on TP removal in the overall facility at the 0.05 level with the maximum TP removal can be obtained to be $86 \%$ at HRT $24 \mathrm{~h}$ and $\mathrm{C}: \mathrm{N}: \mathrm{P}$ ratio 600:60:3.7.

\subsection{Kinetics of nutrient removal}

\subsubsection{Kinetics of nitrogen removal}

Based on Fig. 6, equation (2) was plotted and the result showed that $\mathrm{k}_{1}$ was $1.01 \mathrm{~d}^{-1}$ with the correlation coefficient $\mathrm{R}^{2}=0.36$. Fig. 7 indicated a second-order kinetic model applied to lab-scale model of an on-site 
domestic wastewater facility. The equation (5) was plotted and the results showed that $\mathrm{a}$ and $\mathrm{b}$ were 0.19 $\mathrm{d}^{-1}$ and 1.94 , respectively with correlation coefficient $\mathrm{R}^{2}=0.97$. According to Fig. 8, The Umax and $\mathrm{K}_{\mathrm{B}}$ values were calculated as $166.67 \mathrm{mg} / \mathrm{L} . \mathrm{d}$ and, $316.33 \mathrm{mg} / \mathrm{L} . \mathrm{d}$, respectively with correlation coefficient $\mathrm{R}^{2}=0.97$.

In this research, three kinetic models were applied to nitrogen removal. Table 2 showed the kinetic parameters that were calculated by First Order, Second-order and Stover-Kincannon Models in different experimental conditions. $\mathrm{k}_{1}$ is the first order kinetic model which is considered as the rate of substrate removed by the first

order reaction. [12] Akhbari et al. (2012) found $\mathrm{k}_{1}$ value

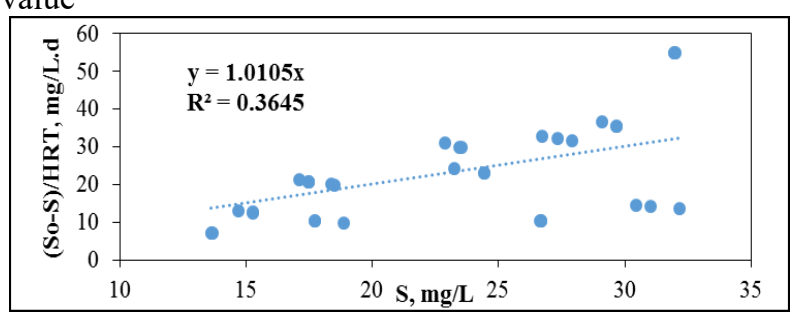

Fig. 6. First-order for TN removal in lab-scale model of an on-site domestic wastewater treatment facility.

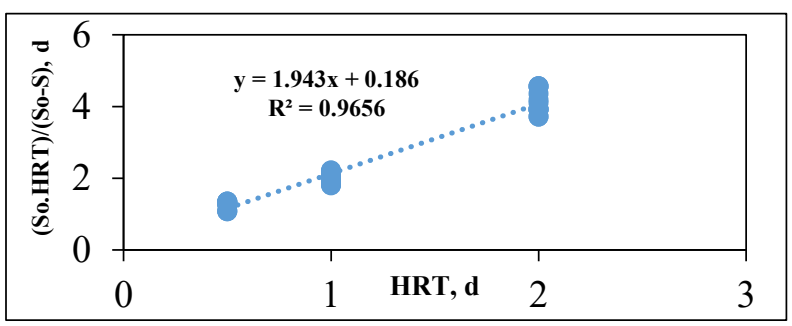

Fig. 7. Second-order for TN removal in lab-scale model of an on-site domestic wastewater treatment facility.

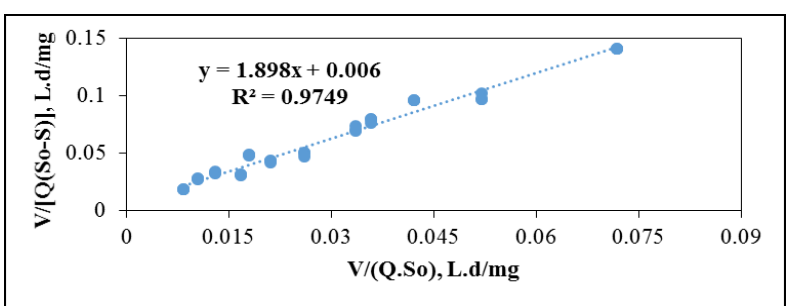

Fig. 8.

Stover-Kincannon Model for TN removal in lab-scale model of an on-site domestic wastewater treatment facility.

to be $1.882 \mathrm{~d}^{-1}$ which was higher than this study. The most likely reason for the difference in $\mathrm{k}_{1}$ value was the significant variation of inlet concentration, type of the reactor, the hydraulic retention time, wastewater characteristic and microorganisms in the facility. Moreover, it can be confirmed that TN removal process is so complex that can not be adequately described slowly by the first order reaction equation with a good degree of precision [13]. The saturation constant $\left(\mathrm{K}_{\mathrm{B}}\right)$ and the maximum utilization rate $\left(\mathrm{U}_{\max }\right)$, the rate constant in Stover-Kincannon model, were found to be $316.33 \mathrm{mg} / \mathrm{L} . \mathrm{d}$ and $166.66 \mathrm{mg} / \mathrm{L} . \mathrm{d}$, respectively. Comparing with the results found by Akhbari et al.
(2012) [12], in this study, $K_{B}$ and $U_{\max }$ values was much lower, but the correlation coefficient was in the similar value. The correlation coefficient $\left(\mathrm{R}^{2}\right)$ in this model was 0.97 which consider as higher precision than the firstorder model. In Second-order substrate removal rate, $\mathrm{k}_{2(\mathrm{~s})}$ is the speed constant at which the pollutant can be removed. Therefore, the higher the $\mathrm{k}_{2(\mathrm{~s})}$, the faster the pollutant can be removed. $\mathrm{k}_{2(\mathrm{~s})}\left(0.1522 \mathrm{~d}^{-1}\right)$ obtained in this study was lower than the one obtained by Akhbari et al. (2012) [11].The $\mathrm{k}_{2(\mathrm{~s})}$ will be increased as substrate removal rate increased depending on initial substrate concentration and microorganism inside the reactor.

\subsubsection{Kinetic of TP removal}

According to Fig. 9, equation (2) was plotted and the result showed that $\mathrm{k}_{1}$ was $1.38 \mathrm{~d}^{-1}$ with the coefficient correlation $\mathrm{R}^{2}=-0.69$. Fig. 10 indicated a second-order kinetic model applied to lab-scale model of an on-site domestic wastewater treatment facility. The equation (5) was plotted and the results showed that $a$ and $b$ were $0.84 \mathrm{~d}^{-1}$ and 2.84 , respectively with correlation coefficient $\mathrm{R}^{2}=0.60$. According to Fig. 11, The Umax and $K_{B}$ values were calculated $1.94 \mathrm{mg} / \mathrm{L} . \mathrm{d}$ and 6.93 $\mathrm{mg} / \mathrm{L} . \mathrm{d}$, respectively after the equation (9) was plotted with correlation coefficient $\mathrm{R}^{2}=0.73$.

In this research, two kinetic models were applied to phosphorus removal in facility. Table 3 presents kinetic parameters for TP removal that were calculated by Second-order and Stover-Kincannon Models in different experimental conditions. The saturation constant $\left(\mathrm{K}_{\mathrm{B}}\right)$ and the maximum utilization rate $\left(\mathrm{U}_{\max }\right)$, the rate constant in Stover-Kincannon model, were found to be $6.93 \mathrm{mg} / \mathrm{L} . \mathrm{d}$ and $1.94 \mathrm{mg} / \mathrm{L} . \mathrm{d}$, respectively. Comparing with the results found by Akhbari et al. (2012) [12], $\mathrm{K}_{\mathrm{B}}$ and $U_{\max }$ values obtained in this study were much lower, but the correlation coefficient was in the similar value. The correlation coefficient in this model was 0.73 which consider as fairly good precision with the data obtained

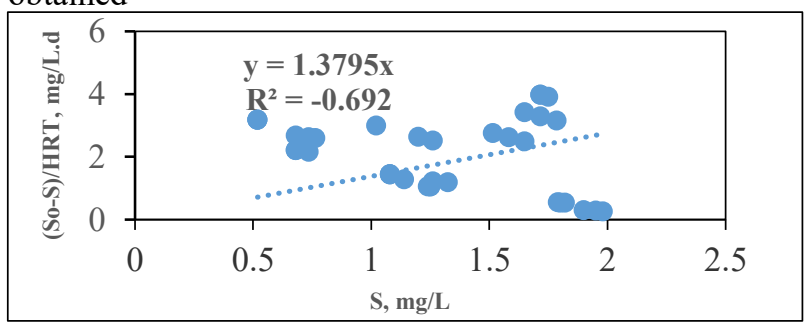

Fig. 9. First order for TP removal in lab-scale model of an on-site domestic wastewater treatment facility.

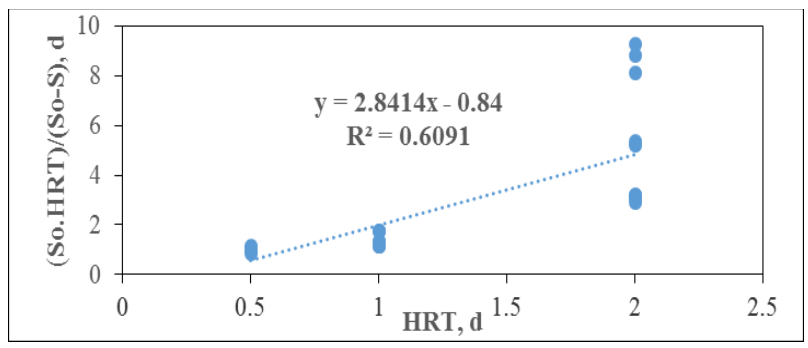

Fig. 10. Second order for TP removal in lab-scale of an on-site domestic wastewater treatment facility. 


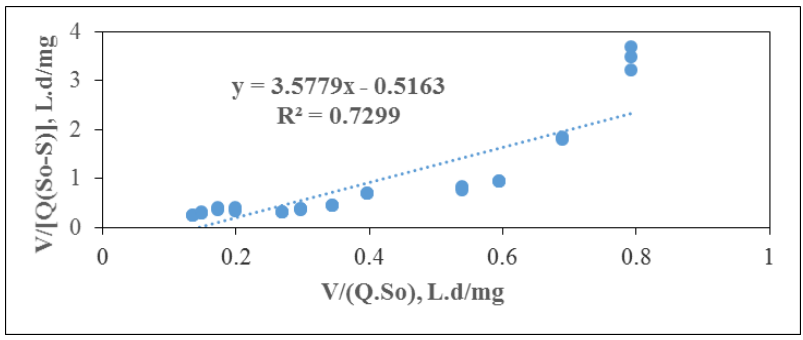

Fig. 11. Stover-Kincannon Model for TP removal in lab-scale model of an on-site domestic wastewater treatment facility.

Table 2. Kinetics of TN removal in lab-scale model of an on-site domestic wastewater treatment facility.

\begin{tabular}{|c|c|c|c|c|c|c|c|}
\hline \multicolumn{2}{|c|}{ First-Order } & \multicolumn{3}{|c|}{ Second-Order } & \multicolumn{3}{c|}{ Stover-Kincannon } \\
\hline $\mathrm{R}^{2}$ & $\begin{array}{c}\mathrm{k}_{1} \\
\left(\mathrm{~d}^{1}\right)\end{array}$ & $\mathrm{R}^{2}$ & $\begin{array}{c}\mathrm{a} \\
\left(\mathrm{d}^{-1}\right)\end{array}$ & $\mathrm{b}$ & $\mathrm{R}^{2}$ & $\begin{array}{c}\text { Umax } \\
(\mathrm{mg} / \mathrm{L} .)\end{array}$ & $\begin{array}{c}\mathrm{KB} \\
(\mathrm{mg} / \mathrm{L} .)\end{array}$ \\
\hline 0.36 & 1.01 & 0.97 & 0.19 & 1.94 & 0.97 & 166.66 & 316.33 \\
\hline
\end{tabular}

Note: $\mathbf{k}_{\mathbf{1}}$ : First-order substrate removal rate constant, $\mathbf{U}_{\max }$ : Maximum substrate removal rate constant, $\mathbf{K}_{\mathbf{B}}$ : Saturation constant.

Table 3. Kinetics of TP removal in lab-scale model of an on-site domestic wastewater treatment facility.

\begin{tabular}{|c|c|c|c|c|c|}
\hline \multicolumn{3}{|c|}{ Second-Order } & \multicolumn{3}{c|}{ Stover-Kincannon } \\
\hline $\mathrm{R}^{2}$ & $\begin{array}{c}\mathrm{a} \\
\left(\mathrm{d}^{-1}\right)\end{array}$ & $\mathrm{b}$ & $\mathrm{R}^{2}$ & $\begin{array}{c}\text { Umax } \\
(\mathrm{mg} / \mathrm{L} . \mathrm{d})\end{array}$ & $\begin{array}{c}\mathrm{KB} \\
(\mathrm{mg} / \mathrm{L} . \mathrm{d})\end{array}$ \\
\hline 0.60 & 0.84 & 2.84 & 0.73 & 1.94 & 6.93 \\
\hline
\end{tabular}

Note: $\mathbf{k}_{1}$ : First-order substrate removal rate constant, $\mathbf{U}_{\text {max }}$ : Maximum substrate removal rate constant, $\mathbf{K}_{\mathbf{B}}$ : Saturation constant

from the experiment. $\mathrm{k}_{2(\mathrm{~s})}\left(0.0024 \mathrm{~d}^{-1}\right)$ obtained in this study was lower than the one obtained from another research conducted by Akhbari et al. (2012) [12].The $\mathrm{k}_{2(\mathrm{~s})}$ will be increased as substrate removal rate increased depending on initial substrate concentration and microorganism inside the facility. Simplified models are formed a few variables and can be used to determine the kinetic of the reactions. Three models were used to investigate the biological reactions, First Order, Second Order and Stover-Kincannon Models. After drawing regression diagrams for these models, second Order and Stover-Kincannon Models showed a very good and high adaptation in removing nitrogen in lab-scale model of an on-site domestic wastewater treatment facility as the determination coefficients were either the removal efficiency or effluent concentration at the field scale when it is operated in similar condition as lab-scale model of an on-site domestic wastewater treatment facility, accurately.

Moreover, the knowledge of kinetics of nutrient removal in this research provides a rational basis for the process analysis and control. It is possible to optimize reactor performance based on the kinetics study. It also gives the reaction rate of the system and provides a basis for reactor design and operation [14].

\subsection{Evaluation of Facility Performance}

Based on Table 4, it showed the predicted results of TN removal by using Second Order and Stover-Kincannon Models. The predicted result of maximum TN removal by using Second Order Substrate Removal Model was $57.87 \%$ based on the equation (6) and the predicted result of TN removal by employing Stover-Kincannon model was $50.4 \%$ according to equation (13). Comparing the maximum $\mathrm{TN}$ removal from experiment and maximum TN removal from kinetic models, they are similar. Based on Table 5, it showed the predicted results of TP removal by using Second Order and Stover-Kincannon Models and maximum TP removal by experiment. The predicted result of maximum TP removal by using Second Order Model was 30.66\% based on the equation (6) and the predicted result of TP removal by employing Stover-Kincannon model was $23.64 \%$ according to equation (13).

Comparing with maximum TP removal from experiment, maximum TP removal from predicted models was lower. This is because of determination coefficient was lower than 0.75 .

Table 4. Predicted results of TN removal by applying Second Order and Stover-Kincannon models and the results of TN removal from the experiment in this facility.

\begin{tabular}{|c|c|c|c|c|}
\hline Model & $\begin{array}{c}\mathbf{a} \\
\mathbf{d}^{-\mathbf{1}}\end{array}$ & $\mathbf{b}$ & $\begin{array}{c}\mathbf{E p} \\
\mathbf{( \% )}\end{array}$ & $\begin{array}{c}\mathbf{E x} \\
\mathbf{( \% )}\end{array}$ \\
\hline Second Order & 0.19 & 1.94 & 57.87 & $56 \%$ \\
\hline Model & $\begin{array}{c}\mathbf{U}_{\max } \\
\mathbf{m g} / \mathbf{l . d}\end{array}$ & $\begin{array}{c}\text { KB } \\
\mathbf{m g} / \mathbf{L . d}\end{array}$ & $\begin{array}{c}\mathbf{E p} \\
\mathbf{( \% )}\end{array}$ & $\begin{array}{c}\mathbf{E x} \\
\mathbf{\%}\end{array}$ \\
\hline $\begin{array}{c}\text { Stover- } \\
\text { Kincannon }\end{array}$ & 166.66 & 316.33 & 50.4 & $56 \%$ \\
\hline
\end{tabular}

Note: Ep: The predicted result of maximum $T N$ removal from the kinetic models, Ex: Result of maximum TN removal from the experiment.

Table 5. Predicted results of TP removal by applying Second Order and Stover-Kincannon models and the results of TP removal from the experiment in this facility.

\begin{tabular}{|c|c|c|c|c|}
\hline Model & $\begin{array}{c}\mathrm{a} \\
\mathbf{d}^{-\mathbf{1}}\end{array}$ & $\mathbf{b}$ & $\begin{array}{c}\mathbf{E p} \\
\mathbf{( \% )}\end{array}$ & $\begin{array}{c}\mathbf{E x} \\
(\mathbf{\%})\end{array}$ \\
\hline Second Order & 0.84 & 2.84 & 30.66 & $86 \%$ \\
\hline Model & $\begin{array}{c}\mathbf{U}_{\max } \\
\mathbf{m g} / \mathbf{l . d}\end{array}$ & $\begin{array}{c}\mathbf{K}_{\mathbf{B}} \\
\mathbf{m g} / \mathbf{L . d}\end{array}$ & $\begin{array}{c}\mathbf{E p} \\
\mathbf{( \% )}\end{array}$ & $\begin{array}{c}\mathbf{E x} \\
\mathbf{\%}\end{array}$ \\
\hline $\begin{array}{c}\text { Stover- } \\
\text { Kincannon }\end{array}$ & 1.93 & 6.92 & 23.64 & $86 \%$ \\
\hline
\end{tabular}

Note: Ep: The predicted result of maximum TP removal from the kinetic models, Ex: Result of maximum TP removal from the experiment.

The result of maximum TN and TP removal from the experiment were $86 \%$ and $56 \%$, respectively. Comparing with modified septic tank conducted by Kimleng and Effendi [15], the performance of TN and TP removal of that research was lower than this research. It indicates that an on-site domestic wastewater treatment facility had achieved good performance of nutrient removal.

\section{Conclusion}

Effect of HRT, initial TN and TP concentration on the performance of TN and TP removal were evaluated. All of the variations gave the significant effect of HRT, initial TN and TP concentration on the performance of nutrient removal. The optimum operating condition can be achieved at HRT of 24h and COD:N:P of 350:38:2.9 for TN removal was $56 \%$ and HRT of $24 \mathrm{~h}$ and COD:N:P of $600: 60: 3.7$ for TP removal was $86 \%$.The kinetics of nutrient removal of lab-scale model of an on-site domestic wastewater facility for treating synthetic wastewater which had been characterized based 
characteristic of wastewater from office building was investigated using three different models such as First Order Substrate Removal, Second Order Substrate Removal, and Stover-Kincannon Models. Second Order and Stover-Kincannon Models were found to be more suitable than First Order Model for prediction of performance of $\mathrm{TN}$ removal in on-site domestic wastewater treatment facility as the correlation coefficients were 0.97 .The maximum predicted results of TN removal efficiencies by applying kinetic models were ranging from 50.48 to $57.87 \%$. It showed that onsite domestic wastewater treatment facility has achieved the good performance of TN removal. Controlling HRT and initial TN and TP concentration may keep good performance of nutrient removal in an on-site domestic wastewater treatment facility.

This research was supported by P3MI KK ITB, Project of JICA ITB III, and Gifu Prefectural Environmental Management and Technology Center, Gifu, Japan.

\section{Nomenclature}

COD: Chemical Oxygen

Demand, (mg/L)

HRT : Hydraulic Retention

Time (h or d)

Q: Flow rate $(\mathrm{L} / \mathrm{d}$ or $\mathrm{L} / \mathrm{h})$

$\mathrm{k}_{1}$ :First-order kinetic constant rate $\left(\mathrm{d}^{-1}\right)$

$\mathrm{k}_{2(\mathrm{~s}) \text { : Second-order kinetic }}$

constant rate $\left(\mathrm{d}^{-1}\right)$

$\mathrm{K}_{\mathrm{B}}$ : Saturation

constant(mg/L.d)

\section{References}

1. Ichinari. T., Ohtsubo. A., Ozawa. T., Hasegawa. K., Teduka. K., Oguchi. T. and Kiso. Y., Wastewater treatment performance and sludge reduction properties of a household wastewater treatment system combined with an aerobic sludge digestion unit, Process Biochem, 43, pp. 722-728, (2008).

2. JECES, Japan Education Center of Environmental Sanitation, (2009).

3. Ormori. D., Nitrogen and Phosphorous Removal Technology in Johkasou System, Proceeding of Johkasou Session, Kyoto, Japan, (2003).

4. Yang. X.M., Morita.A., Nakano, I., Kushida. Y. and Ogawa., H., History and current situation of night soil treatment systems and decentralized wastewater treatment system in Japan. Water Prac. Technol. 5(4), (2010).

5. Fajri. J.A., Yamada. T., Setiyawan.A.S. and Fusheng. L., Evaluation of water and sediment quality in open channels that received effluent from Johkasou facility, J Water Environ Technol, 13(3), pp. 2017-208, (2015).

6. Matsuo. T., Japanese experienced in water pollution control and wastewater treatment technologies, Water Sci. Technol, 42 (12), pp. 163172, (2000).

7. Vandith. V., Setiyawan. A.S. and Soewondo. P., Kinetics of organic removal in Johkasou as anonsite domestic wastewater treatment system, The
Fourth Joint Seminar of Japan and Indonesia: Environmental Sustainability and Disaster Prevention (ESDP), Bandung, Indonesia, (2016).

8. Reeves. E. G., Kinetic Analysis of Kluyvermyces Maximum Yeast Strain Louisiana, (2004).

9. Jin. R. and Zheng. P., Kinetic of nitrogen removal in high rate anammox upflow filter, Hazard. Mater, 170 (2), pp. 652-656, (2009).

10. Grau. P., Dohanyas. M. and Chudoba. J., Kinetic of multicomponent substrate removal by activated sludge, Water res, 9, pp. 637-642, (1975).

11. Yu. H., Wilson. F. and Tay. J., Kinetics analysis of an anaerobic filter treating soybean wastewater, Water Res, 32(11), pp. 3341-3352, (1998).

12. Akhbari. A., Zinatizadeh. A. L., Mohammadi. P., Mansouri. Y., Irandoust. M. and Isa. M. H., Kinetic modeling of carbon and nutrients removal in integrated rotating biological contactor-activated sludge system, Int.J.Environ. Sci. Technol, 9, pp. 371-378, 2012.

13. Mansouri. A. M., Zinatizadeh. A. L. and Akabari. A., Kinetic Evaluation of Simultaneous CNP Removal in an up-Flow Aerobic/Anoxic Sludge Fixed Film (UAASFF) Bioreactor, IJEE, 5(3), pp. 323-336, (2014).

14. Isik. R. and Sponza. T., Substrate removal kinetics in an upflow anaerobic sludge blanket reactor decolorizing simulated textile wastewater, Process Biochem, 40, pp. 1189-1198, (2005).

15. Kimleng. T. and Effendi. A. J., COD removal kinetics and microorganisms growth kinetics using lab-scale batch condition for toilet wastewater treatment in modified septic tank using plastic media, Master thesis, Bandung, Indonesia, (2016). 